\title{
PENGARUH PENGGUNAAN MODEL PEMBELAJARAN PROBLEM BASED LEARNING TERHADAP HASIL PRESTASI BELAJAR MENULIS EKSPLANASI DITINJAU DARI ASPEK MOTIVASI BELAJAR SISWA (Studi Eksperimen di Kelas XI SMA Negeri Pacitan)
}

\author{
Dhinda Permata Neriasari ${ }^{1}$, Esti Ismawati ${ }^{2}$ \\ Program Pendidikan Bahasa Program Pasca Sarjana Universitas Widya Dharma Klaten \\ estisetyadi@gmail.com
}

\begin{abstract}
Abstrak
Penelitian ini bertujuan menghitung besarnya pengaruh penggunaan model pembelajaran Problem Based Learning ( $P B L$ ), motivasi belajar siswa, dan interaksi antara penggunaan model pembelajaran $P B L$ dan motivasi belajar siswa terhadap prestasi hasil belajar siswa menulis eksplanasi. Penelitian ini menggunakan metode eksperimen jenis quasi. Variabel bebasnya model pembelajaran $P B L$ dan motivasi belajar siswa, sedangkan variabel terikatnya hasil prestasi belajar siswa menulis eksplanasi. Data dikumpulkan dengan kuesioner dan tes. Teknik analisis data dengan uji hipotesis analisis variansi dua jalan dengan sel tak sama. Hasil penelitian menyimpulkan bahwa model Problem Based Learning lebih efektif daripada metode ceramah; motivasi belajar siswa tinggi, dan tidak ada interaksi antara penerapan model pembelajaran $P B L$ dan motivasi belajar siswa terhadap hasil prestasi belajar siswa menulis eksplanasi.
\end{abstract}

Kata kunci: Problem Based Learning, motivasi belajar, menulis eksplanasi

\begin{abstract}
This research is aimed to know the side effect of using problem based learning to the students' writing explanation achievement, to know the students' motivation in learning to the students' academic achievement, to know the interactions between the use of problem based learning method and the students' motivation in learning to students' writing explanation. The method used is Quasi Experimental study. They are two variable in this research, the first is free variable which is contain problem based learning model and students' motivation in learning. The second, is bound variable which is contain the students achievement in writing explanation. The data taken uses questionaire and test. The technique of analyzing the data is using two ways variants by using different cell in analysis hypothesis. The research result shows that the problem based learning model is more effective than lecturer method by applying the students' writing explanation. The second, the higher students' motivation in learning is more effective than the lower students' motivation in learning to the students' academic achievement in writing explanation. The third, there aren't positive interaction between applying the problem based learning and students' motivation to the students' academic achievement.
\end{abstract}

Keywords: Problem Based Learning, students'motivation, writing explanation 


\section{PENDAHULUAN}

Undang-undang No. 20 Tahun 2003 tentang Sisdiknas menyebutkan bahwa pendidikan adalah usaha sadar dan terencana untuk mewujudkan suasana belajar dan proses pembelajaran agar peserta didik secara aktif mengembangkan potensi dirinya untuk memiliki kekuatan spiritual keagamaan, pengendalian diri, kepribadian, kecerdasan, akhlak mulia, serta keterampilan yang diperlukan dirinya, masyarakat, bangsa dan negara. Dalam pelaksanaannya, pendidikan yang diharapkan adalah pendidikan yang bermutu atau berkualitas. Kualitas pendidikan meliputi presentase produk yang dihasilkan peserta didik; proses pendidikan mengenai pengelolaan kelas dan metode pengajaran; serta ketersediaan sumber pendidikan. Secara umum, kualitas pendidikan meliputi empat kriteria, yaitu (1) kualitas awal peserta didik, (2) penggunaan dan pemilihan sumber-sumber pendidikan yang berkualitas, (3) proses belajar mengajar, dan (4) output pendidikan (Zainuddin, 2008:3). Komponen-komponen ini mengandaikan keseluruhannya berada di dalam jangkauan guru, tanpa reserve.

Di lain pihak, banyak masalah yang dihadapi para pendidik sekarang ini, di antaranya maraknya pemakaian alat-alat sosial media, adanya kurikulum baru, dan kurangnya minat dan motivasi siswa dalam belajar di kelas. Hal ini dapat disebabkan berbagai faktor, antara lain: (1) guru belum menguasai materi yang diajarkan; (2) kurangnya strategi guru dalam kegiatan belajar mengajar di kelas; dan (3) metode pembelajaran yang diterapkan guru membuat siswa menjadi cepat jenuh dan kurang menarik perhatian siswa. Kurikulum baru yang membuat guru belum siap mengantar materi tersebut juga menjadi kendala serius di lapangan meski MGMP terus digalakkan dan guru inti terus didekatkan pada kelompokkelompok guru pebelajar. Di tangan guru yang cerdas dan berwawasan luas tidak akan terjadi kendala, sebaliknya di tangan guru yang masih muda sering terjadi kendala. Penelitian ini akan melihat besarnya pengaruh penggunaan model pembelajaran Problem Based Learning (PBL), motivasi belajar siswa, dan interaksi antara penggunaan model pembelajaran $P B L$ dan motivasi belajar siswa terhadap prestasi hasil belajar siswa menulis eksplanasi. 


\section{KAJIAN TEORI}

Dalam Kurikulum Bahasa Indonesia 2016 Kelas XI terdapat materi teks eksplanasi. Materi ini cukup menyita perhatian guru terutama dalam hal membuat contoh-contohnya. Teks eksplanasi adalah teks yang berisi tentang proses mengapa dan bagaimana suatu peristiwa alam, ilmu pengetahuan, sosial, budaya, dan lainnya bisa terjadi. Suatu peristiwa baik peristiwa alam maupun sosial yang terjadi di sekitar kita, selalu mempunyai hubungan sebab akibat dan proses (Depdikbud, 2016). Ciri-ciri teks eksplanasi adalah, strukturnya terdiri dari penyataan umum, urutan sebab akibat, dan interpretasi; Informasi yang dimuat berdasarkan fakta (faktual). Faktual tersebut memuat informasi yang bersifat

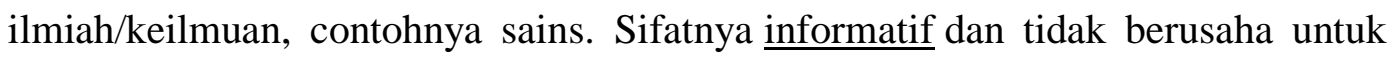
mempengaruhi pembaca untuk percaya terhadap hal yang dibahas. Memiliki / menggunakan sequence markers. Seperti pertama, kedua, ketiga, dan sebagainya. Bisa juga menggunakan: pertama, berikutnya, terakhir.

\section{Struktur Teks Eksplanasi}

Seperti yang tertulis dalam ciri teks eksplanasi di atas, teks ini mempunyai tiga struktur yang membangunnya agar menjadi satu kesatuan yang utuh. Struktur teks eksplanasi terdiri atas, pertama, pernyataan umum yang berisi pernyataan umum mengenai topik yang akan dijelaskan proses proses terjadinya/proses keberadaan. Kedua, urutan sebab akibat yang berisi tentang detail penjelasan proses terjadinya yang disajikan secara urut atau bertahap dari yang paling awal hingga yang paling akhir. Ketiga, interpretasi yang berisi tentang kesimpulan mengenai topik yang telah dijelaskan. Pembelajaran teks eksplanasi di kelas XI dicoba dengan metode baru, yakni Problem Based Solving (PBL).

\section{Kaidah Kebahasaan Teks Eksplanasi}

Di dalam teks eksplanasi mengandung ciri kaidah kebahasaan berikut, pertama, fokus pada hal umum (generic), bukan partisipan manusia (nonhuman participants). Contoh: tsunami, banjir, gempa bumi, hujan, dan udara. Kedua, dimungkinkan menggunakan istilah ilmiah. Ketiga, lebih banyak menggunakan verba material dan verba relasional (kata kerja aktif). Keempat, menggunakan konjungsi waktu dan kausal seperti sehingga, sebelum, 
pertama, jika, bila, dan kemudian. Kelima, menggunakan kalimat pasif. Keenam, teks eksplanasi ditulis untuk membuat justifikasi bahwa sesuatu yang diterangkan secara kausal itu benar adanya. Contoh:

Judul: Gerhana Bulan

\section{Pernyataan Umum (Pembuka)}

Gerhana bulan merupakan salah satu fenomena alam yang sering kita jumpai. Peristiwa alam ini terjadi apabila bulan beroposisi dengan matahari. Namun, oposisi bulan dengan matahari tidak akan selamanya menghasilkan peristiwa gerhana bulan.

\section{Deretan Penjelas (Isi)}

Faktanya, ketika terjadi gerhana bulan, sebenarnya penampakan bulan masih dapat terlihat. Hal ini disebabkan karena sinar matahari yang masih tersisa, berbelok menuju arah bulan oleh atmosfer bumi. Sinar matahari yang dibelokkan itu tentu memiliki spektrum cahaya kemerahan, yang merupakan alasan mengapa saat peristiwa gerhana bulan, tampilan bulan akan terlihat lebih gelap, biasanya berwarna merah gelap, jingga atau bahkan coklat.

\section{Penutup (Interpretasi)}

Ketika bayangan bumi menutupi sebagai atau seluruh penampang bulan, maka pada saat itulah akan terjadi gerhana bulan. Terutama ketika bumi menempati posisi di antara matahari dan bulan, dan berada pada satu garis lurus yang sama, yang kemudian membuat sinar Matahari tidak dapat mencapai bulan karena dihalangi oleh posisi bumi saat itu (Alfari, 2018).

Pembahasan lengkap mengenai pengertian teks eksplanasi yang dilengkapi dengan contoh singkat beserta strukturnya dapat menjadi bekal baik untuk guru maupun siswa di dalam pembelajaran teks eksplanasi dengan metode PBL.

Berdasarkan fakta di kelas, pembelajaran menulis eksplanasi merupakan salah satu kesulitan yang dialami siswa sekarang, khususnya kelas XI SMA Negeri di Pacitan. Hal ini disebabkan karena kurangnya motivasi belajar siswa dan model pembelajaran yang diterapkan guru kurang menarik. Untuk itu, diperlukan suatu penelitian dengan metode eksperimen, sehingga hasilnya nanti bisa dibandingkan dengan model pembelajaran yang sebagaimana mestinya guru mengajar. Metode 
eksperimen adalah suatu metode atau cara yang dilakukan dengan diberikan salah satu perlakuan khusus, yang mana tujuannya dapat meningkatkan hasil prestasi belajar siswa.

Salah satu perlakuan yang dapat meningkatkan hasil prestasi belajar siswa yaitu dengan menerapkan model pembelajaran Problem Based Llearning. Model pembelajaran ini sangat membantu siswa dalam memahami materi yang sedang diajarkan oleh guru karena model pembelajaran ini bersifat student centered atau berpusat pada siswa. Model ini berbasis pada masalah sehingga siswa lebih aktif, inovatif dan kreatif (Sugiyanto, 2010). Jadi dapat diartikan bahwa model pembelajaran Problem Based Learning adalah model pembelajaran berbasis masalah, yang berfokus pada siswa, sehingga siswa bisa lebih aktif, kreatif, dan inovatif dalam menyampaikan pendapat atau gagasan yang disampaikan.

Adapun tujuan penelitian ini adalah (1) menghitung pengaruh penggunaan model pembelajaran Problem Based Learning terhadap hasil prestasi belajar siswa menulis eksplanasi; (2) menghitung pengaruh motivasi belajar siswa terhadap hasil prestasi belajar siswa menulis eksplanasi; dan (3) menghitung ada tidaknya interaksi antara penggunaan model pembelajaran Problem Based Learning dan motivasi belajar siswa terhadap hasil prestasi belajar siswa menulis eksplanasi.

\section{METODE PENELITIAN}

Penelitian ini menggunakan rancangan eksperimen semu (quasi experimental research) karena bertujuan untuk mengungkapkan hubungan sebab akibat dengan cara melibatkan kelas kontrol dengan kelas eksperimen. Pada kelas kontrol siswa diberikan model pembelajaran sebagaimana mestinya guru mengajar (metode ceramah), sedangkan pada kelas eksperimen siswa diberikan perlakuan dengan menerapkan model pembelajaran problem based learning.

Penelitian ini dilakukan di SMA Negeri Pacitan, Kabupaten Pacitan, Provinsi Jawa Timur. SMA Negeri di Pacitan ada dua sekolah yaitu SMA Negeri 1 Pacitan dan SMA Negeri 2 Pacitan.

Sampel dipilih secara acak yaitu dengan menggunakan metode multy stage random sampling. Sampel dalam penelitian ini adalah semua siswa kelas XI IPS 2 
SMA Negeri 2 Pacitan sebagai kelas eksperimen sedangkan semua siswa kelas XI IPS 1 SMA Negeri 1 Pacitan sebagai kelas kontrol.

Metode pengumpulan data yang digunakan adalah metode angket/ kuesioner, metode tes, dan metode dokumentasi. Metode angket/ kuesioner untuk mengumpulkan data pada variabel model problem based learning (untuk guru dan siswa) dan motivasi belajar siswa (untuk siswa). Metode tes untuk mengumpulkan data pada variabel hasil prestasi belajar siswa menulis eksplanasi. Metode dokumentasi penelitian ini adalah hasil prestasi belajar siswa sebelum diterapkan model pembelajaran dan setelah diterapkan model pembelajaran.

Selanjutnya instrumen angket/ kuesioner dilakukan validasi menggunakan korelasi product moment dan dilakukan uji reliabilitas menggunakan Alpha Cronbach. Sedangkan instrumen tes dilakukan validasi oleh guru yang bersangkutan (guru Bahasa Indonesia Kelas XI) SMA Negeri I Pacitan di dalam kelas tersebut.

Selanjutnya dilakukan tahapan teknik analisis data sebagai berikut:

1. Uji Keseimbangan menggunakan uji $\mathrm{t}$

2. Uji Prasyarat Analisis (meliputi Uji Normalitas (menggunakan model Liliefors) dan Uji Homogenitas (menggunakan uji Bartlett))

3. Uji Hipotesis Penelitian menggunakan ANAVA dua jalan sel tak sama.

\section{HASIL PENELITIAN}

Instrumen penelitian model pembelajaran problem based learning untuk siswa sebelumnya dilakukan uji coba pada kelas kontrol dan kelas eksperimen. Setelah diujicobakan pada kelas eksperimen yang gagal sebanyak 2 butir soal sedangkan pada kelas kontrol yang gagal sebanyak 1 butir soal. Dikatakan butir soal gagal karena $80 \%$ dari total siswa memilih jawaban yang sama, yakni pada item nomor 1, $80 \%$ dari total siswa memilih jawaban selalu. Sedangkan pada instrumen motivasi belajar siswa juga dilakukan uji coba pada kelas kontrol dan kelas eksperimen. Hasil uji coba pada kelas eksperimen yang gagal sebanyak 3 butir soal dan pada kelas kontrol yang gagal sebanyak 0 butir soal (tidak ada soal yang gagal). Hal ini dikarenakan pada kelas kontrol semua siswa menjawab pilihan secara seimbang. 
Instrumen hasil prestasi belajar siswa dilakukan dengan tes uraian yang divalidasi oleh guru mata pelajaran yang bersangkutan (guru bahasa Indonesia). Tes uraian kelas eksperimen dan kelas kontrol adalah sama, karena untuk membandingkan hasil prestasi belajar siswa menggunakan model problem based learning dengan metode ceramah.

Hasil reliabilitas variabel model PBL (siswa) awal kelas eksperimen sebesar 0,788; model PBL (siswa) akhir kelas eksperimen sebesar 0,694; model PBL (siswa) awal kelas kontrol sebesar 0,873; model PBL (siswa) akhir kelas kontrol sebesar 0,817; model PBL (guru) kelas eksperimen dan kelas kontrol sebesar 0,958.

Hasil reliabilitas variabel motivasi belajar siswa kelas eksperimen (awal) sebesar 0,594; motivasi belajar siswa kelas eksperimen (akhir) sebesar 0,617; motivasi belajar siswa kelas kontrol (awal) sebesar 0,813; motivasi belajar siswa kelas kontrol (akhir) sebesar 0,819.

Berdasarkan hasil analisis terlihat bahwa dari masing-masing nilai hasil analisis Alpha Cronbach diperoleh angka lebih dari 0,600, yang memiliki arti nilai tersebut adalah reliabel.

Berikut hasil tahapan analisis data:

1. Uji Keseimbangan (kesimpulan: kelas mempunyai kemampuan awal yang sama artinya kelas kontrol dan kelas eksperimen mempunyai nilai kemampuan (pretest) yang sama).

2. Uji Prasyarat Analisis

a. Uji Normalitas dengan Metode Lilliefors (kesimpulan: sampel berasal dari populasi yang berdistribusi normal).

b. Uji Homogenitas (kesimpulan: variansi dari dua populasi tersebut sama atau homogen).

\section{Uji Hipotesis}

Berikut tabel rekapitulasi analisis variansi dua jalan sel tak sama:

\begin{tabular}{llllll} 
Sumber & JK & dk & RK & $F_{\text {obs }}$ & $\boldsymbol{F}_{\alpha}$ \\
\hline
\end{tabular}




\begin{tabular}{lccccc}
\hline Metode (A) & 950,8725 & 1 & 950,8725 & 19,088 & 4,036 \\
Motivasi (B) & 573,372 & 2 & 286,686 & 6,483 & 3,186 \\
Interaksi (AB) & 98,7928 & 2 & 49,3964 & 1,228 & 3,186 \\
Galat & $1.953,899$ & 51 & 38,3117 & - & - \\
\hline Total & $3.576,9363$ & 56 & & & \\
\hline
\end{tabular}

Dari hasil tabel analisis di atas dapat dijelaskan sebagai berikut, (1) Model pembelajaran PBL lebih efektif daripada metode ceramah terhadap hasil prestasi belajar siswa menulis eksplanasi. (2) Motivasi belajar siswa tinggi lebih efektif daripada motivasi belajar rendah terhadap hasil prestasi belajar siswa menulis eksplanasi. (3) Tidak ada interaksi antara model pembelajaran PBL dan motivasi belajar siswa terhadap hasil prestasi belajar siswa menulis eksplanasi.

\section{PEMBAHASAN HASIL PENELITIAN}

Model pembelajaran PBL lebih efektif daripada metode ceramah terhadap hasil prestasi belajar siswa menulis eksplanasi. Berdasarkan hasil penelitian tersebut diperkuat dari hasil penelitian Dastgeer, Ghulam, Afzal, Muhammad Tanveer, et al (2015), yang mengatakan bahwa model PBL adalah metode belajar mengajar dimana siswa bekerja di lingkungan yang berpusat pada peserta didik dalam kelompok kecil 4-5 menghadapi masalah otentik yang diberikan oleh guru dan menemukan solusinya dengan cara mendiskusikan dengan kelompoknya. Selain itu, juga diperkuat teori Rusman (2010:232-233) tentang karakteristik pembelajaran berbasis masalah, yang mana permasalahan menjadi starting point dalam belajar.

Motivasi belajar siswa tinggi lebih efektif daripada motivasi belajar rendah terhadap hasil prestasi belajar siswa menulis eksplanasi. Berdasarkan hasil penelitian tersebut diperkuat teori Sardiman (2016:73) yang mengemukakan bahwa motivasi berasal dari kata "motif" yang diartikan sebagai daya upaya mendorong seseorang untuk melakukan sesuatu dan dapat dikatakan sebagai daya penggerak dari dalam dan di dalam subjek untuk melakukan aktivitas-aktivitas tertentu demi mencapai suatu tujuan, sehingga diartikan sebagai suatu kondisi intern (kesiapsiagaan).

Tidak ada interaksi antara penerapan model problem based learning dan motivasi belajar siswa terhadap hasil prestasi belajar siswa menulis eksplanasi. 
Berdasarkan hasil penelitian tersebut diperkuat teori Tan (2013) dalam Rusman (2010:229) yang mengemukakan bahwa pembelajaran berbasis masalah merupakan inovasi dalam pembelajaran karena dalam PBM kemampuan berpikir siswa betulbetul dioptimalisasikan melalui proses kerja kelompok atau tim yang sistematis, sehingga siswa dapat memberdayakan, mengasah, menguji, dan mengembangkan kemampuan berpikirnya secara berkesinambungan. Selain itu juga diperkuat teori Sukandi (2011:12) yang mengemukakan bahwa motivasi diartikan sebagai kekuatan (energy) penggerak seseorang yang dapat menimbulkan tingkat peristensi dan entusiasmenya dalam melaksanakan suatu kegiatan, baik yang bersumber dari dalam diri individu sendiri (motivasi intrinsik) maupun dari luar individu (motivasi ekstrinsik).

\section{KESIMPULAN}

Dari hasil dan pembahasan di atas dapat disimpulkan bahwa (1) Model Pembelajaran Problem Based Learning lebih efektif daripada metode ceramah terhadap hasil prestasi belajar siswa menulis eksplanasi. (2) Motivasi belajar siswa tinggi lebih efektif daripada motivasi belajar siswa rendah terhadap hasil prestasi belajar siswa menulis eksplanasi. (3) Tidak ada interaksi antara penerapan model pembelajaran problem based learning dan motivasi belajar siswa terhadap hasil prestasi belajar siswa menulis eksplanasi.

\section{DAFTAR PUSTAKA}

Ahmadi, Abu, dkk. 2008. Psikologi Belajar. Jakarta: PT. Rineka Cipta.

Akhadiah, Sabarti, dkk. 2010. Menulis. Jakarta: Departemen Pendidikan dan Kebudayaan.

Alfari, Shabrina, 2018. Teks Eksplanasi. www.materikelas.com/2015/10/tekseksplanasi-pengertian-struktur.html).

Anni, Chatarina Tri. 2016. Psikologi Belajar. Semarang: UPT UNNES Press.

Arikunto, Suharsimi. 2010. Dasar-dasar Evaluasi Pendidikan. Jakarta: Bumi Aksara.

Budiyono. 2014. Statistik Untuk Penelitian Edisi 1. Surakarta: UNS Press. . 2010. Statistik Untuk Penelitian Edisi 2. Surakarta: UNS Press. 
Bungel, Moh. Fikri. 2014. Penerapan Model Pembelajaran Problem Based Learning Untuk Meningkatkan Hasil Belajar Siswa Kelas VIII SMP Negeri 4 Palu Pada Materi Prisma. Jurnal Online.

Dastgeer, Ghulam, Afzal, Muhammad Tanveer, et al (2015). Improving English Writing Skills: A Case of Problem Based Learning. American Journal of Education Research, Vol. 3, Nomor 10 (2015): 1315-1319. doi: 10.12691/education-3-10-17.

Depdikbud, 2016. Kurikulum Bahasa Indonesia SMA, MA, SMK.

Dharma, I.P Suyoga, Marhaeni, AAIN., Budasi, IG., et al (2014). The Effect of Problem Based Learning and Performance Assessment on Students Reading and Writing Competences. E-Journal Program Pascasarjana Universitas Pendidikan Ganesha, Program Studi Pendidikan Bahasa Inggris, Volume 2 Tahun 2014.

Gardner, Robert C., Wilson, Annie., Bernaus, Merce., et al (2009). Teachers motivation, classroom strategy use, students motivation and second language achievement. Porta Linguarum 12, junio 2009, pp. 2-36.

Hastomo, Tommy. (2015). The Effectiveness of Edmodo to Teach Writing Viewed from Students Motivation. Prosiding ICCTTE FKIP UNS 2015, ISSN: 2502-4124, Vol 1, Nomor 1, Januari 2016.

Irawati, Enny., Jumariati., et al (2017). Problem-Based Learning in English Writing Classroom: A Study on Students Perceptions toward Its Impacts. International Journal of English and Education, ISSN: 2278-4012, Volume:6, Issue:3, July 2017.

Iswandari, Dyah Christina., Prayogo, Johannes Ananto., Cahyono., Bambang Yudi., et al (2017). Effect of Environmental Problem-based Learning on the Indonesian EFL Students Environment-related Vocabulary Mastery and Writing Ability. Theory and Practice in Language Studies, Vol. 7, No. 8, pp. 608-616, August 2017.

Majid, Abdul. 2017. Perencanaan Pembelajaran: Mengembangkan Standar Kompetensi Guru. Bandung: PT. Remaja Rosdakarya.

Meilani, Rini Intansari., Suminar, Serra Oktafoura., et al (2016). Pengaruh Model Pembelajaran Discovery Learning and Problem Based Learning terhadap Prestasi Belajar Peserta Didik. Jurnal Pendidikan Manajemen Perkantoran, Volume 1, Nomor 1, Agustus 2016, Halaman 84-93. 
Noviani, Siska Ulfa. 2015. Peningkatan Keterampilan Menyusun Teks Eksplanasi Secara Tertulis Menggunakan Model Pembelajaran Berbasis Masalah (Problem Based Learning) Pada Peserta Didik Kelas VII A SMP Negeri 19 Tegal Tahun Pelajaran 2014/2015. Skripsi. Semarang: Program Studi Pendidikan Bahasa dan Sastra Indonesia Fakultas Bahasa dan Seni Universitas Negeri Semarang.

Nurgiyantoro, Burhan. 2015. Penilaian Pembelajaran Bahasa. Yogyakarta: BPFEYogyakarta.

Rahimi, Mehrak, Karkami, Fatemeh Hosseini, et al (2015). The role of teachers classroom discipline in their teaching effectiveness and students language learning motivation and achievement: A path method. Iranian Journal of Language Teaching Research 3(1), (Januari, 2015) 57-82.

Rasyid, Harun, Mansur. 2017. Penilaian Hasil Belajar. Bandung: CV Wacana Prima.

Romanza, Eky. 2014. Studi Eksperimen Hasil Belajar Mata Pelajaran Bahasa Indonesia dengan Menggunakan Media Powerpoint Siswa Kelas 5C SD N 9 Bengkulu Selatan. Skripsi. Bengkulu: Program Studi Pendidikan Guru Sekolah Dasar Jurusan Ilmu Pendidikan Fakultas Keguruan dan Ilmu Pendidikan Universitas Bengkulu.

Rusman. 2011. Model-model Pembelajaran: Mengembangkan Profesionalisme Guru. Jakarta: PT. RajaGrafindo Persada.

Sardiman, A.M. 2010. Interaksi dan Motivasi Belajar Mengajar. Jakarta: Grafindo Persada.

Soemarsono. 2017. Strategi Belajar Mengajar. Surakarta: UPT Penerbitan dan Pencetakan UNS (UNS Press).

Souriyawongsa T., Raob I., Abidin Z. J. M., et al (2012). Study on Students Motivation in Joining An English Course. Journal of Education and Learning. Vol. 6 (3) pp. 147-154.

Sugiyanto, 2010. Model-model Pembelajaran Inovatif. Surakarta: Panitia Sertifikasi Guru Rayon 13 FKIP UNS Surakarta.

Sugiyono. 2010. Statistika untuk Penelitian. Bandung: Alfabeta. 2011. Metode Penelitian Kuantitatif Kualitatif dan R\&D. Bandung: Alfabeta.

Suharsimi, Arikunto. 2010. Prosedur Penelitian Suatu Pendekatan Praktik. Jakarta: Rineka Cipta. 
Sukandi. 2011. Pengaruh Kemampuan Mengajar Guru Terhadap Motivasi Belajar Siswa SMK Negeri di Kabupaten Indramayu. Tesis. Jakarta: Fakultas Ilmu Sosial dan Ilmu Politik, Departemen Ilmu Administrasi Program Pascasarjana, Kekhususan Administrasi dan Kebijakan Pendidikan Universitas Indonesia.

Supriadi, Oding. 2013. Perkembangan Peserta Didik. Yogyakarta: Kurnia Kalam Semesta.

\section{PRESSindo.}

2013. Profesi Kependidikan. Yogyakarta: LaksBang

Undang-undang No. 20 Tahun 2003 tentang Sisdiknas

Wulandari, Bekti. 2013. Pengaruh Problem Based Learning terhadap Hasil Belajar ditinjau dari Motivasi Belajar PLC di SMK. Jurnal Pendidikan Vokasi, Vol 3, Nomor 2, Juni 2013.

Zainuddin. 2008. Reformasi Pendidikan: Kritik Kurikulum dan Manajemen Berbasis Sekolah. Yogyakarta: Pustaka Pelajar. 